\title{
Foraging ecology of subantarctic fur seals Arctocephalus tropicalis breeding on Amsterdam Island: seasonal changes in relation to maternal characteristics and pup growth
}

\author{
Gwénaël Beauplet $^{1, *}$, Laurent Dubroca ${ }^{1}$, Christophe Guinet $^{1}$, Yves Cherel $^{1}$, \\ Willy Dabin ${ }^{2}$, Céline Gagne ${ }^{1}$, Mark Hindell ${ }^{3}$ \\ ${ }^{1}$ Centre d'Etudes Biologiques de Chizé, Centre National de la Recherche Scientifique, 79360 Villiers en Bois, France \\ ${ }^{2}$ Centre de Recherche sur les Mammifères Marins, Av. Lazaret, Port des Minimes, 17000 La Rochelle, France \\ ${ }^{3}$ Antarctic Wildlife Research Unit, School of Zoology, University of Tasmania, PO Box 252-05, Hobart 7001, Tasmania, Australia
}

\begin{abstract}
The distribution and availability of marine resources are directly affected by seasonal spatial changes in physical and oceanographic features. They are thus likely to influence maternal foraging provisioning patterns, efficiency, and subsequent pup growth rate of central place foragers such as otariid seals. While previous studies have documented foraging locations and diving activity of female otariids in relation to oceanographic features, few have focused on species characterised by a long pup-rearing period. The present study investigated seasonal changes in foraging parameters in relation to the following oceanographic features and maternal characteristics: foraging grounds (using satellite tags, geolocation, GIS and kernel estimation techniques), at-sea activity budget (using time-depth recorders), and the foraging success and diet of female subantarctic fur seals Arctocephalus tropicalis breeding on Amsterdam Island (southern Indian Ocean). The seals mainly exploited the subtropical front, but also exhibited large differences in seasonal distribution, from short trips in restricted foraging areas during summer to widely distributed foraging grounds during the winter. This is consistent with a seasonal shift in diet and an increasing proportion of time being dedicated to diving and resting. This increase in foraging trip duration throughout the season paralleled decreasing rates in maternal mass gain and pup growth, suggesting a decrease in food availability. During the summer, maternal mass gain rate and pup growth were related to foraging tactics (percent of time spent diving and in the core foraging area), whereas maternal characteristics such as body length were more important during the latter months of the pup-rearing period. However, no influence of age and thus no apparent advantage of female experience was detected in this study.
\end{abstract}

KEY WORDS: Foraging ecology · Activity budget - Seasonal changes · Maternal performances · Pup growth · Fur seal · Arctocephalus tropicalis · Amsterdam Island

Resale or republication not permitted without written consent of the publisher

\section{INTRODUCTION}

In marine ecosystems, the distribution and availability of marine resources are generally related to the spatial heterogeneity of physical and oceanographic features (Mann \& Lazier 1991). This heterogeneity can affect all levels of the trophic web, from phytoplankton to marine top-predator populations (Croxall 1992). The spatial and temporal patterns in behaviour of a highlevel marine predator can, therefore, provide valuable insights into the spatial distribution of marine resources (McConnell et al. 1992, Pakhomov \& McQuaid 1996, Guinet et al. 1997, Georges et al. 2000). In the case of breeding 'central place foragers', the prospecting range and consequent resource accessibility are restricted by the great distances the animals 
regularly have to travel between the location of their marine prey and their breeding grounds (Orians \& Pearson 1979). Consequent foraging performances must therefore be directly affected by this restricted resource availability within the prospecting area of the animal. Hence, breeding seabirds such as albatrosses can monitor intra-annual oceanographic features, as they have to cope with constraints imposed by the different stages of their breeding cycle and by temporal changes in prey availability and distribution (Weimerskirch et al. 1993, Ydenberg et al. 1994).

Similarly, otariid seals (fur seals and sea lions) can also be used as oceanographic indicators, as maternal care consists in a long period (4 mo to 3 yr) of successive foraging cycles, defined as a long foraging trip at sea followed by a short period ashore to feed the pup (Gentry \& Kooyman 1986, Wartzok 1991). Maternal foraging ranges are thus limited by the pup's requirements as well as by the female's own swimming and diving ability. The spatial and temporal separation between the feeding zones and the rookery present some energetic constraints during the pup-rearing process: a seal has to catch prey located sometimes far from the rookery, store the energy acquired and then transfer it to its pup as lipid-rich milk (Gentry \& Kooyman 1986, Georges et al. 2001, Arnould \& Hindell 2002). The connection between the marine environment and reproductive performance therefore occurs through resource acquisition and allocation processes, and imposes important nutritional and energetic costs.

Several recent studies of female fur seals have documented at-sea diving activity in relation to oceanographic features (Boyd et al. 1998, Guinet et al. 2001). During years of normal food availability, females exhibiting shorter trips were shown to maximise the proportion of time spent diving while minimising the time spent travelling and recovering between dives (Boyd et al. 1994, Arnould et al. 1996, Boyd 1996). Moreover, when food resources were scarce, seals exhibited longer foraging trips, which led to a decline in pup growth rate (Lunn et al. 1993, Goldsworthy 1995). These investigations, however, involved the Antarctic fur seal Arctocephalus gazella, a species with relatively short pup-rearing periods (i.e. 4 mo) compared to the subantarctic fur seal $A$. tropicalis breeding at Amsterdam Island (Georges \& Guinet 2000a), where females rear their single offspring over a 10 mo period (Tollu 1974), during which they alternate foraging trips at sea and fasting visits ashore to suckle their pup (Georges \& Guinet 2000a). In temperate latitudes, such a long rearing period probably reflects major seasonal changes in environmental conditions (Belkin \& Gordon 1996). Variable and unpredictable distribution in prey patches throughout time and space is thus expected to lead to variability in fur seal foraging patterns (Boyd 1999). In response to this varying resource availability, females are expected to adjust their at-sea time budgets in order to optimise the rate of energy delivery to the offspring (Houston et al. 1996). Such use of different foraging tactics throughout the season is expected to maximise the growth and survival of their young under different environmental conditions (Stephens \& Krebs 1986).

The relationships between seasonal patterns of oceanographic features, foraging distribution and efficiency, and the factors affecting maternal performances and subsequent pup growth have not been documented in a long-lactating fur seal species. Georges et al. (2000) hypothesised that sea-surface temperature could be used as a locational cue to identify the fur seal foraging grounds, but this has yet to be more precisely documented through the help of satellite and geolocation tracking.

The aims of the present study, therefore, were to determine seasonal changes in (1) foraging areas in relation to oceanographic features, (2) diet, (3) at-sea activity budget, and (4) the factors influencing maternal input and subsequent pup growth rate in subantarctic fur seal females breeding at Amsterdam Island.

\section{MATERIALS AND METHODS}

Study site and seals. The study was conducted at the La Mare aux Elephants breeding colony, on the NE side of Amsterdam Island, where one of the largest breeding colonies is located (Roux 1987, Guinet et al. 1994). This island ( $37^{\circ} 55^{\prime} \mathrm{S}, 77^{\circ} 30^{\prime} \mathrm{E}$ ) lies in the southern Indian Ocean, $3000 \mathrm{~km}$ from Africa, Australia and Antarctica (Fig. 1) and up to $400 \mathrm{~km}$ from the subtropical front (STF, delimited by the 10.6 and $17.9^{\circ} \mathrm{C}$ surface isotherms; Lutjeharms \& Valentine 1984). Female subantarctic fur seals give birth to a single pup within a few days of arrival, from late November to early January, with a mean parturition date in mid-December (Georges \& Guinet 2000b). Hereafter, the breeding seasons are designated by the year in which weaning occurred (i.e. 1999 for the 1998-1999 breeding season), and the pup-rearing period was divided into 4 phases defined as summer (mid-January to midFebruary), early autumn (mid-February to end of March), late autumn (mid-April to end of May) and winter (June-July).

During the 1999 and 2002 parturition period (28 November to 8 January), 200 newborn pups were sexed, weighed $( \pm 0.05 \mathrm{~kg})$, and identified by a numbered piece of plastic tape glued to the fur on the top of the head (Georges \& Guinet 2000b). At approximately 


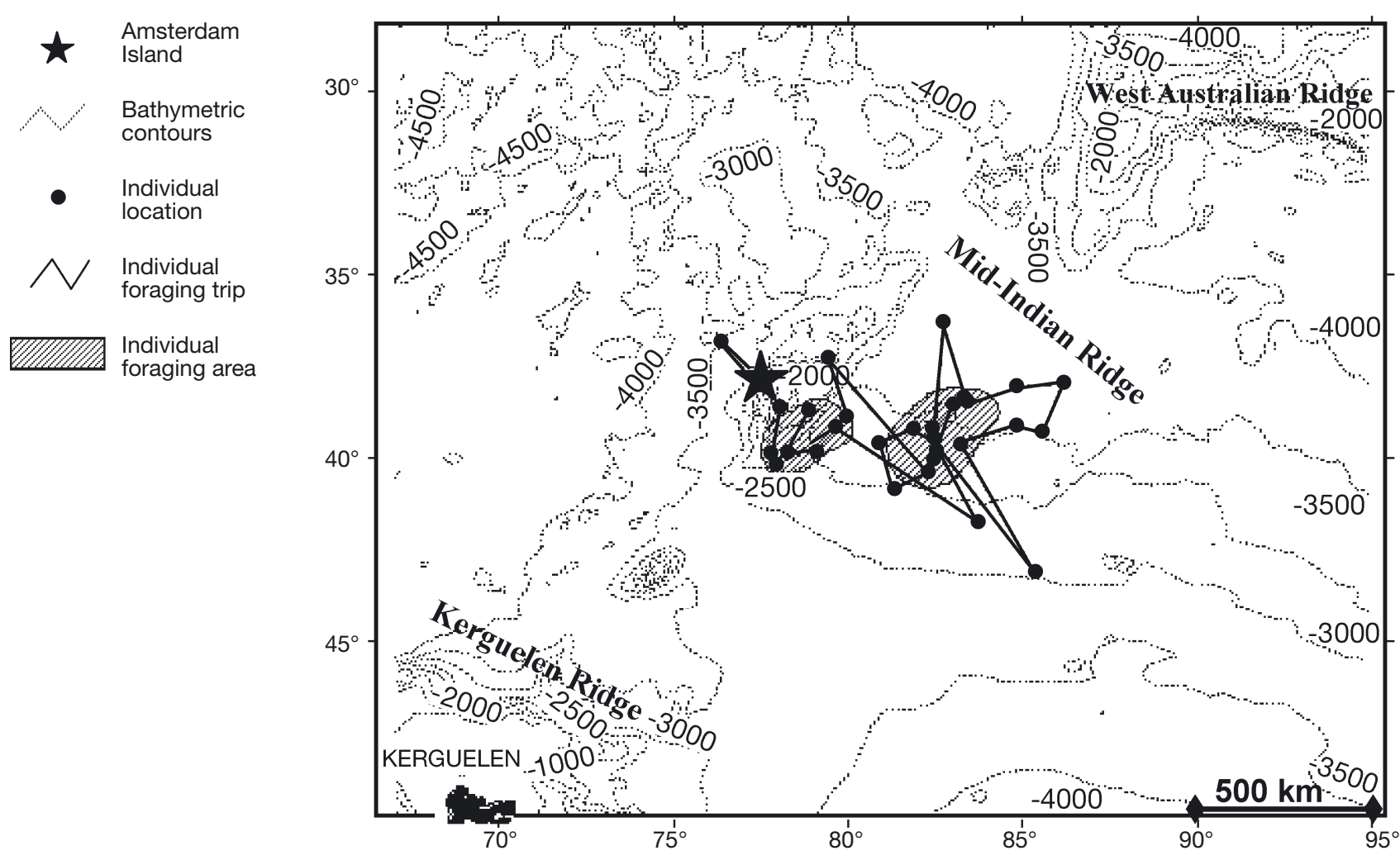

Fig. 1. Topography of study area surrounding Amsterdam Island, with sea depth indicated by isometric lines (500 m increments). Example of foraging trip of female Arctocephalus tropicalis is shown, with data points representing successive locations of the seal. The 2 foraging zones on this trip are indicated by shaded areas and were determined by kernel analysis

1 mo of age, each pup was tagged on the trailing edge of both fore-flippers with an individually numbered plastic tag (Dalton Rototag, Nettlebed, UK). Mother-pup pairs were selected at random from this group of known-age pups, between mid-April and end of July 1999, and from mid-January to mid-March 2002, respectively. During the 1999 and 2002 breeding seasons, we observed similar patterns of seasonal sea surface temperature (SST) changes (see 'Results'), and the pup growth rates were also similar (Chambellant et al. 2003). We therefore considered the 1999 and 2002 sampling periods as a single pup-rearing period.

Device attachment. At-sea behaviour was investigated for one single foraging trip for 23 and 18 lactating females in 1999 and 2002, respectively. Once its pup was selected, the female was captured at the end of her time ashore (i.e. after a few days of a suckling period) using a hoop net. Each seal was weighed using a spring scale $(200 \pm 1 \mathrm{~kg})$, measured $( \pm 1 \mathrm{~cm})$, and then immobilised on a restraint board (Gentry \& Kooyman 1986) for 10-20 min while the device was attached; 2 types of devices were deployed. (1) A platform terminal transmitter (PTT, Telonics ST10, packaged by Sirtrack; $120 \mathrm{~g}, 110 \times 42 \times 14 \mathrm{~mm}$, cross-sectional area $5.7 \mathrm{~cm}^{2}$ ) linked to an Argos system (Taillade 1993) was deployed on 8 seals in 1999. (2) A time-depth recorder (TDR; MK7, Wildlife Computers; $27 \mathrm{~g}, 86 \times 20 \times 11 \mathrm{~mm}$, cross-sectional area $2.2 \mathrm{~cm}^{2}$ ) was deployed on 19 seals in 1999 (including 4 deployed concurrently with a PTT) and 18 seals in 2002. The devices were attached with plastic cable ties to a nylon webbing strap $(110 \times$ $42 \mathrm{~mm}$ for PTTs and $86 \times 20 \mathrm{~mm}$ for TDRs, respectively) that was glued to the dorsal fur with double component Araldite glue (AW 2101, Ciba) on the midline between the scapulae (for PTTs) or $10 \mathrm{~cm}$ anterior to the tail of the seal (for TDRs).

Continuous monitoring of the colony during daytime allowed us to catch returning females when they arrived ashore after 1 foraging trip. Upon final recapture, the seals were weighed before device retrieval, anaesthesia (Dabin et al. 2002) and subsequent removal of the lower left post-canine 1 for age determination (see Dabin et al. in press).

Pup weighing. Each tagged pup was regularly (every 2-3 d) weighed using a rope attached to a spring scale $( \pm 0.1 \mathrm{~kg})$, with particular attention paid to the periods immediately preceding and following maternal attendance. Once its mother was captured for device deployment, regular weighing of the pups during the maternal foraging trip confirmed that no food 
was consumed during that time. Upon the mother's final capture, the pup was weighed, measured, and returned to its mother. Pup recapture occurred just after the mother's departure for its next foraging trip, in order to assess pup mass gain. It was then again regularly weighed until weaning, as previously described.

Diet. The subantarctic fur seal diet in subtropical waters is essentially unknown. However, previous studies on various fur seal species exploiting subantarctic waters showed that fishes constituted the main component of their diet (Ochoa-Acuna \& Francis 1995, Klages \& Bester 1998, Robinson et al. 2002). Therefore, only the fish-component diet was assessed within the scope of this study. Fish otoliths and bones were examined from 132 fresh faecal samples collected throughout the 1999 pup-rearing period from the rookery where females were known to suckle their pups. These samples were assumed to be representative of lactating subantarctic fur seals at the La Mare aux Elephants breeding colony. Individual scats were stored frozen $\left(-20^{\circ} \mathrm{C}\right)$ in individual plastic bags until laboratory analysis. For analysis, the faecal samples were thawed in warm water and rinsed through 1.0 and $0.5 \mathrm{~mm}$ sieves to collect hard prey remains. Fish otoliths were extracted and identified to species using the descriptions in Smale et al. (1995) and by comparison with our own reference collection. However, we were unable to make a clear distinction between Symbolophorus barnardi and $S$. boops, as the shapes of their otoliths are very similar (Smale et al. 1995). We therefore pooled those species together under the name of Symbolophorus spp.

Spatial analyses. Locations obtained with PTTs were derived from referring to 3 satellites and assigned by Argos to 1 of 6 accuracy classes (Table 1). The accuracy of locations depends primarily on the number of uplinks received. The real error incurred was assessed by comparing location fixes recorded while the seals were in the colony (e.g. before they went to sea after device attachment). Considering the distance between

Table 1. Accuracy of location fixes for all class types (location quality) obtained by Argos satellite telemetry for all seals during time spent in breeding colony. na: not available

\begin{tabular}{|c|c|c|c|c|c|}
\hline \multirow{2}{*}{ Class } & \multirow{2}{*}{$\begin{array}{l}\text { Argos } \\
\text { Accuracy } \\
(\mathrm{km})\end{array}$} & \multirow{2}{*}{$\bar{n}$} & \multicolumn{2}{|c|}{ — Transmitter fixes } & \multirow[b]{2}{*}{$\begin{array}{c}\text { Range } \\
(\mathrm{km})\end{array}$} \\
\hline & & & $\begin{array}{l}\text { Mean accu- } \\
\text { racy }(\mathrm{km})\end{array}$ & $\begin{array}{c}\mathrm{SD} \\
(\mathrm{km})\end{array}$ & \\
\hline 3 & 0.15 & 89 & 0.4 & 0.3 & $0.0-1.5$ \\
\hline 2 & $0.15-0.35$ & 103 & 1.1 & 0.7 & $0.0-5.5$ \\
\hline 1 & $0.35-1.00$ & 119 & 1.3 & 1.2 & $0.1-7.4$ \\
\hline 0 & $>1.00$ & 144 & 7.0 & 6.7 & $0.5-30.5$ \\
\hline A & na & 34 & 4.1 & 7.5 & $0.7-35.5$ \\
\hline B & na & 29 & 10.8 & 15.9 & $0.3-66.4$ \\
\hline
\end{tabular}

the epicentre of the $200 \mathrm{~m}$-wide colony (determined by GPS) and each actual location provided by Argos, we estimated a mean error for each class (Table 1). All classes were then included in these analyses, as the maximum error found was considerably smaller than that observed with the geolocation method (Hill 1994, LeBœuf et al. 2000). Argos data were plotted using Elsa97 software (Release 1.1, Soft \& Technique Informatique).

The MK7-TDRs were programmed to record wet and dry periods, temperature and light level every $5 \mathrm{~s}$. The light level data allowed us to obtain 2 seal positions per day, derived from geolocation software (Multi-trace, Jensen Software). This provided an estimate of latitude and longitude, based on the timing of dawn and dusk (see Hill 1994, LeBœuf et al. 2000). When comparing distances between fixes obtained from the 4 individuals equipped with both Argos and TDR tags (Table 2), mean distance estimated between geolocation and satellite positions was similar to that found in previous studies (Hill 1994, LeBouf et al. 2000). When considering a large-scale area (i.e. $1^{\circ}$ precision), Argos and geolocation records exhibited similar tracks for the 4 seals, leading us to consider the 2 methods comparable for this study.

For both sets of data, obtained by either the Argos system or geolocation method, location fixes were filtered such that those requiring transit speeds greater than $3 \mathrm{~m} \mathrm{~s}^{-1}$ between successive fixes were discarded (Bonadonna et al. 2000). After the filtering process, we ended up retaining 318 fixes (out of 392) of the Argos location data, containing only $3 \%$ of Classes A and B (initial proportion $63 \%$ ). Similarly, we retained 1400 fixes (out of 1600) of the geolocation data.

Environmental data. Environmental conditions were estimated from sea-surface temperature (SST) measured through satellite remote-sensing. These data, as well as bathymetric contours of the study area, were obtained from the Integrated Global Ocean Service System (Reynolds \& Smith 1994: http://ingrid.ldeo. columbia.edu/SOURCES/IGOSS). SST data were extracted monthly at a $1^{\circ}$ scale during the corresponding period of device deployments.

Table 2. Estimated distance between geolocation and Argos location fixes for 4 seals equipped with both Argos and TDR (time-depth recorder) tag

\begin{tabular}{|lcccc|}
\hline \multirow{2}{*}{$\begin{array}{l}\text { Argos } \\
\text { Class }\end{array}$} & $\mathrm{n}$ & $\begin{array}{r}\text { Mean distance } \\
(\mathrm{km})\end{array}$ & $\begin{array}{c}\text { SD } \\
(\mathrm{km})\end{array}$ & $\begin{array}{c}\text { Range } \\
(\mathrm{km})\end{array}$ \\
\cline { 2 - 5 } & & & 102 & $0-321$ \\
$1-3$ & 11 & 67 & 80 & $0-295$ \\
0 & 35 & 125 & 80 & $0-213$ \\
A-B & 11 & 67 & 86 & $0-321$ \\
All & 57 & 114 & & \\
\hline
\end{tabular}


Foraging trips of lactating female fur seals consist of a round trip from a central place to a foraging ground where the seal concentrates its search for food; consequently, a higher fix density can be observed in this area (Bonadonna et al. 2000, Georges et al. 2000, Guinet et al. 2001). We therefore used kernel density estimators (Silverman 1986), a non-parametric technique, to quantitatively delineate the foraging areas (Wood et al. 2000), defined as surfaces where a maximum density of fixes occurs ('core'). We used the 'Animal Movement' extension (Hooge \& Eichenlaub 1997) to GIS ArcView (ESRI). Kernel analysis was initially performed on each foraging trip (Fig. 1), and the relationship between the probability of use (percentages of fixes) and the percentage of area was plotted. The intersection of the tangent with a slope of -1 represented the boundaries of the individual core (Powell 2000). A second kernel analysis was then performed on those core fixes in order to define the main core area used per season for the population (see Pinaud \& Weimerskirch 2002).

Calculations. Maternal body mass was measured on both deployment and recovery of the devices. However, as the mothers often remained ashore after instrument deployment, we used the equation of Georges \& Guinet (2000a) to estimate the maternal weight at departure. The masses obtained just after their subsequent return ashore enabled us to calculate the maternal mass gain (MMG) after a single foraging trip (Guinet \& Georges 2000).

Pup mass gain (PMG), was the difference between pup mass obtained before a mother returned from its tracked foraging trip and after maternal departure for its next foraging trip. Maternal and pup mass gain rates were defined as the individual absolute mass gain divided by the time the mother spent foraging. We also calculated pup growth rate (GR) using the equation

$$
\operatorname{GR}\left(\mathrm{g} \mathrm{d}^{-1}\right)=\left(M_{\mathrm{F}}-M_{\mathrm{I}}\right) /\left(T_{\mathrm{F}}-T_{\mathrm{I}}\right)
$$

where $M$ represents the mass at time $T$, with $I$ representing the day prior to the maternal attendance period when the device was deployed, and $F$ representing the day prior to the maternal arrival ashore 2 foraging cycles later.

We identified 3 primary at-sea activities using the TDR records during maternal foraging trips: diving, travelling, and resting at the surface (Dubroca et al. unpubl.). Fur seals usually 'porpoise' while travelling, and thus alternate short and very shallow dives $(<4 \mathrm{~m})$ with short surface intervals (Boyd 1996). In contrast, when resting at sea, fur seals float at the surface either grooming or remaining motionless. The diving activity was thus associated with greater depth than the dive threshold (i.e. $4 \mathrm{~m}$ ), whereas surface travelling and resting behaviours were differentiated using the variability level of the depth records during the inter-dive interval. To assess this variability, the $\mathrm{SD}$ of the depth records was determined over an optimal time window (Dubroca et al. unpubl.): a seal was considered to be resting at the surface when the SD of inter-dive interval depth was zero, whereas any other inter-dive interval period was considered as travelling time (Dubroca et al. unpubl.). All the activity budget treatment and analyses were carried out using R software (Ihaka \& Gentleman 1996), and the computing of these analyses was made on a openMosix cluster system (www.openmosix.org) at the computer network of Centre d'Oceanologie de Marseille.

All statistical analyses followed the methods of Sokal \& Rohlf (1981), and were performed with SYSTAT 9.0 statistical software (SYSTAT, 9.0 statistics, SPSS). The Kolmogorov-Smirnov test was used to determine whether the data were normally distributed and an F-test was applied to confirm the homogeneity of variances. $\mathrm{G}^{2}$ tests were used to compare the global at-sea activity budget between seasons. Comparisons of means between seasons were made using analyses of variance ANOVA with post-hoc Bonferroni tests. Otherwise, the Mann-Whitney test or Kruskal-Wallis (K-W) 1-way analysis of variance by ranks were used. Wilcoxon paired-sample tests were run to compare atsea activity differences according to presence or absence in the core area. When multivariate analyses were run, correlations were statistically analysed using general linear model (GLM) and the contribution of significant factors was assessed using a backward stepwise analysis (level of rejection $\mathrm{p}>0.1$ ). Unless otherwise stated, values are reported as means \pm SD and statistical significance was considered to be $\mathrm{p}<0.05$.

\section{RESULTS}

\section{Foraging trip duration and spatial distribution}

A total of 41 maternal foraging trips were monitored during the 1999 and 2002 breeding seasons (Table 3). For each season, Mann-Whitney $U$-tests showed no significant difference in duration with those of 35 tagged lactating females without equipment (summer: $U=202, \mathrm{p}=0.92$; early autumn: $U=158, \mathrm{p}=0.88$; late autumn: $U=215, \mathrm{p}=0.24$; winter: $U=362, \mathrm{p}=0.33$ ). Moreover, foraging trip duration increased significantly throughout the pup-rearing period (K-W: $H=$ 5.88, df $=2, p=0.05$, Fig. 2).

In summer, fur seals concentrated their foraging activity in an area restricted to $0-600 \mathrm{~km} \mathrm{~S}$ and SE of the breeding colony (Fig. 3a). They mainly foraged in 
Table 3. Arctocephalus tropicalis. Deployment date and foraging trip durations in 41 lactating subantarctic fur seals on Amsterdam Island. c: complete trip; i: incomplete trip; desertion: mother deserted pup. TDR: time-depth recording; ARG: Argos transmitter

\begin{tabular}{|c|c|c|c|c|c|c|}
\hline $\begin{array}{l}\text { Seal } \\
\text { tag }\end{array}$ & $\begin{array}{l}\text { Departure } \\
\text { (d/mo/yr) }\end{array}$ & $\begin{array}{l}\text { Return } \\
\text { (d/mo/yr) }\end{array}$ & $\begin{array}{l}\text { Duration } \\
\text { (d) }\end{array}$ & $\begin{array}{l}\text { No. days } \\
\text { recorded }\end{array}$ & Season & $\begin{array}{c}\text { Maximum } \\
\text { distance }(\mathrm{km})\end{array}$ \\
\hline TDR & $16 / 01 / 02$ & $26 / 01 / 02$ & 10 & $\mathrm{C}$ & Summer & 437 \\
\hline TDR & 18/01/02 & 03/02/02 & 16 & $\mathrm{C}$ & Summer & 802 \\
\hline TDR & $21 / 01 / 02$ & $16 / 03 / 02$ & 54 & $40 \mathrm{i}$ & Summer & 633 \\
\hline TDR & $23 / 01 / 02$ & $09 / 02 / 02$ & 17 & $\mathrm{C}$ & Summer & 566 \\
\hline TDR & $25 / 01 / 02$ & $11 / 02 / 02$ & 17 & $\mathrm{C}$ & Summer & 754 \\
\hline TDR & $26 / 01 / 02$ & $13 / 02 / 02$ & 18 & $\mathrm{C}$ & Summer & 699 \\
\hline TDR & $28 / 01 / 02$ & $15 / 02 / 02$ & 18 & $\mathrm{C}$ & Summer & 849 \\
\hline TDR & $24 / 01 / 02$ & 06/02/02 & 13 & $\mathrm{C}$ & Summer & 409 \\
\hline TDR & $28 / 01 / 02$ & $07 / 02 / 02$ & 10 & $\mathrm{C}$ & Summer & 545 \\
\hline TDR & $24 / 01 / 02$ & $21 / 02 / 02$ & 28 & $\mathrm{C}$ & Early autumn & 1120 \\
\hline TDR & $29 / 01 / 02$ & $01 / 03 / 02$ & 31 & $\mathrm{C}$ & Early autumn & 1610 \\
\hline TDR & $14 / 02 / 02$ & $13 / 03 / 02$ & 27 & $\mathrm{C}$ & Early autumn & 1121 \\
\hline TDR & $14 / 02 / 02$ & $07 / 03 / 02$ & 21 & C & Early autumn & 976 \\
\hline TDR & $18 / 02 / 02$ & $03 / 04 / 02$ & 44 & $40 \mathrm{i}$ & Early autumn & 722 \\
\hline TDR & $19 / 02 / 02$ & 08/03/02 & 17 & $\mathrm{C}$ & Early autumn & 801 \\
\hline TDR & $18 / 02 / 02$ & $11 / 03 / 02$ & 21 & $\mathrm{C}$ & Early autumn & 1331 \\
\hline TDR & $19 / 02 / 02$ & $10 / 03 / 02$ & 19 & C & Early autumn & 726 \\
\hline TDR & $22 / 02 / 02$ & $20 / 03 / 02$ & 26 & C & Early autumn & 454 \\
\hline ARG & 17/04/99 & 05/05/99 & 18 & $\mathrm{C}$ & Late autumn & 612 \\
\hline ARG & 18/04/99 & 06/05/99 & 18 & $\mathrm{C}$ & Late autumn & 780 \\
\hline ARG & $19 / 04 / 99$ & $15 / 05 / 99$ & 26 & $6 \mathrm{i}$ & Late autumn & 620 \\
\hline TDR & $20 / 04 / 99$ & $30 / 04 / 99$ & 10 & $\mathrm{C}$ & Late autumn & 629 \\
\hline TDR & $21 / 04 / 99$ & $13 / 05 / 99$ & 22 & $\mathrm{C}$ & Late autumn & 1333 \\
\hline ARG & $21 / 04 / 99$ & $21 / 05 / 99$ & 30 & $17 \mathrm{i}$ & Late autumn & 1266 \\
\hline TDR & $23 / 04 / 99$ & $18 / 05 / 99$ & 25 & $\mathrm{C}$ & Late autumn & 1242 \\
\hline TDR & 28/04/99 & 01/06/99 & 34 & $\mathrm{C}$ & Late autumn & 1695 \\
\hline TDR & $22 / 04 / 99$ & $24 / 05 / 99$ & 32 & $25 \mathrm{i}$ & Late autumn & 1288 \\
\hline TDR & $22 / 04 / 99$ & $01 / 05 / 99$ & 9 & $\mathrm{C}$ & Late autumn & 788 \\
\hline TDR & $23 / 04 / 99$ & $23 / 05 / 99$ & 30 & $25 \mathrm{i}$ & Late autumn & 1418 \\
\hline TDR & $25 / 04 / 99$ & $22 / 05 / 99$ & 27 & $25 \mathrm{i}$ & Late autumn & 968 \\
\hline TDR & $23 / 04 / 99$ & $15 / 05 / 99$ & 22 & $\mathrm{C}$ & Late autumn & 675 \\
\hline TDR+ARG & $24 / 05 / 99$ & 03/06/99 & 10 & C & Late autumn & 221 \\
\hline TDR+ARG & $25 / 05 / 99$ & 07/07/99 & 43 & $39 \mathrm{i}$ & Winter & 1564 \\
\hline TDR+ARG & 10/06/99 & $30 / 07 / 99$ & 50 & $40 \mathrm{i}$ & Winter & 1310 \\
\hline TDR & $14 / 06 / 99$ & 03/07/99 & 19 & $\mathrm{C}$ & Winter & 889 \\
\hline TDR & 17/06/99 & 12/07/99 & 25 & $\mathrm{C}$ & Winter & 736 \\
\hline TDR & 19/06/99 & 27/06/99 & 8 & $\mathrm{C}$ & Winter & 346 \\
\hline TDR & $22 / 06 / 99$ & $12 / 07 / 99$ & 20 & $\mathrm{C}$ & Winter & 725 \\
\hline TDR & 28/06/99 & 10/08/99 & 43 & $40 \mathrm{i}$ & Winter & 1262 \\
\hline TDR & 03/07/99 & 28/07/99 & 25 & $\mathrm{C}$ & Winter & 1404 \\
\hline TDR+ARG & $12 / 07 / 99$ & $16 / 12 / 99$ & Desertion & $40 \mathrm{i}$ & Winter & 1885 \\
\hline
\end{tabular}

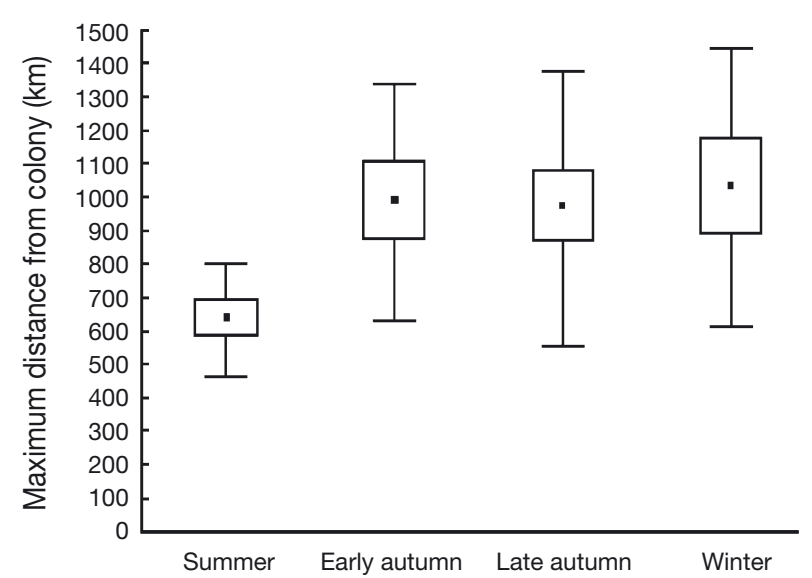

waters of $12.5-18.5^{\circ} \mathrm{C}$, corresponding to the northern part of the STF. During early autumn, the travel directions taken from the rookery were similar, but the range and duration of foraging trips were extended (Fig. 2). The seals concentrated their foraging activity within the whole range of the STF, at 300-900 km S, SE and, to a lesser extent, SW of the breeding colony (Fig. 3b). Moreover, some females went as far as 900-1200 km SSE of the rookery in waters of $6.5-10.5^{\circ} \mathrm{C}$, corresponding to the northern part of the subantarctic front (SAF).

In late autumn, foraging trip direction was similar for all seals, and all travelled SE of Amsterdam Island, as far as $1600 \mathrm{~km}$ from the breeding colony (Fig. 3c). The main foraging areas were located in waters of $10.5-16.5^{\circ} \mathrm{C}$, which corresponds to the southern part of the STF. However, 2 seals went $200 \mathrm{~km} \mathrm{NW}$ and $1300 \mathrm{~km}$ SE of Amsterdam Island, respectively (Fig. 3c). During the winter period, the seals mainly travelled to the $\mathrm{E}$ and $\mathrm{NE}$ of the breeding colony at $100-600 \mathrm{~km}$ and 1000-1800 km (i.e. West Australian Ridge) from the rookery, respectively (Fig. 3d). However, 2 seals, travelled 500-1000 km NW of the island. All foraging zones were scattered in areas with an

Fig. 2. Arctocephalus tropicalis. Seasonal fluctuations in mean distance from rookery and corresponding foraging trip duration for female subantarctic fur seals breeding in Amsterdam Island. Black squares: seasonal mean values; open squares: SE; error bars: SD 
a



c

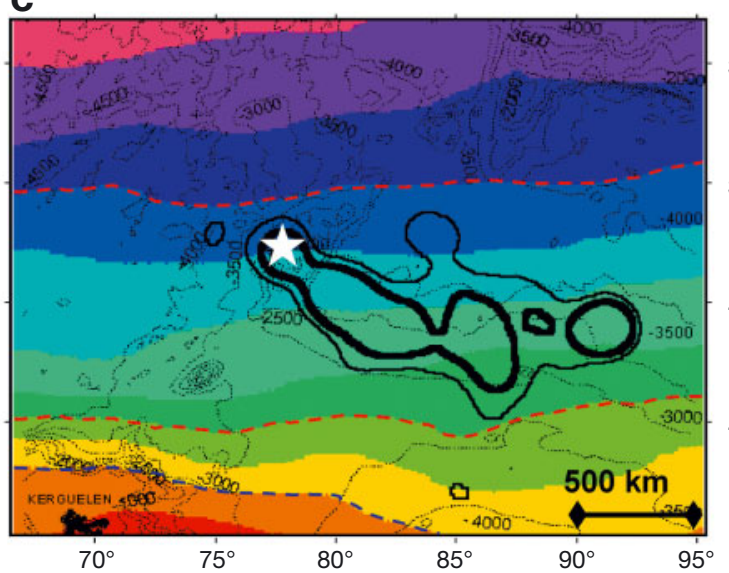

b

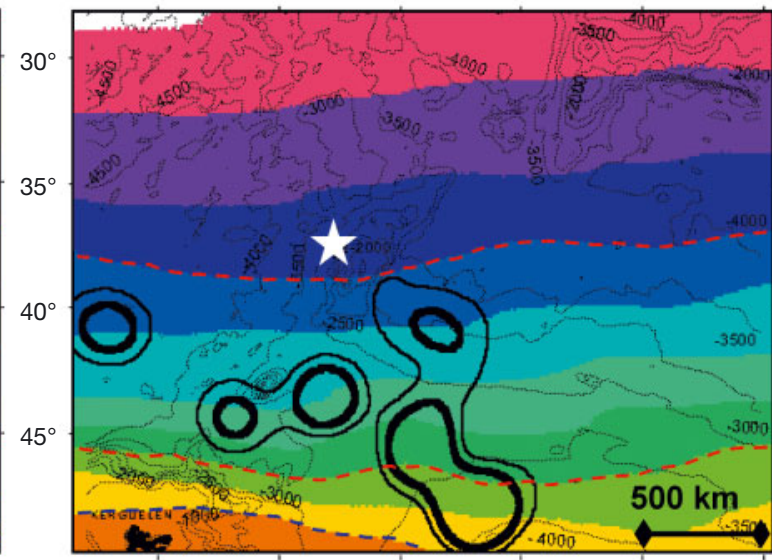

d

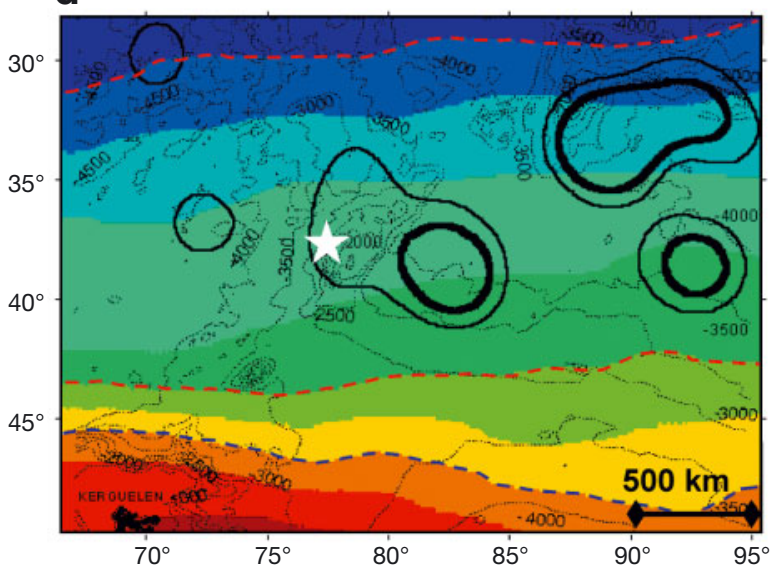

Amsterdam Island

Bathymetric contours

Contour level $55 \%$ L. D. Contour level $75 \%$ L. D.

SST:

$0.5-2.5^{\circ} \mathrm{C}$

2.5-4.5 ${ }^{\circ} \mathrm{C}$

4.5-6.5 ${ }^{\circ} \mathrm{C}$

$6.5-8.5^{\circ} \mathrm{C}$

$8.5-10.5^{\circ} \mathrm{C}$

$10.5-12.5^{\circ} \mathrm{C}\{---$

$12.5-14.5^{\circ} \mathrm{C}$

$14.5-16.5^{\circ} \mathrm{C}$

$16.5-18.5^{\circ} \mathrm{C}-\ldots$

18.5-20.5 ${ }^{\circ} \mathrm{C}$

20.5-22. $5^{\circ} \mathrm{C}$

22.5-24. $5^{\circ} \mathrm{C}$

24.5-26. $5^{\circ} \mathrm{C}$

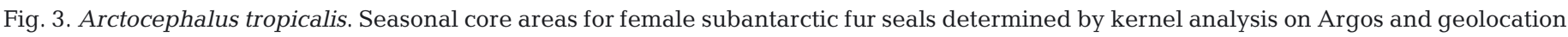

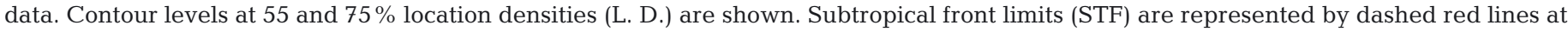

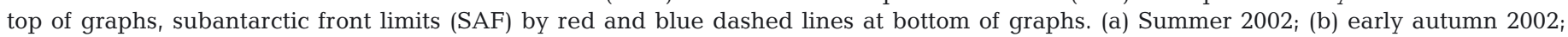

(c) late autumn 1999; (d) winter 1999

SST of $11.5-18.5^{\circ} \mathrm{C}$, excluding areas of lower bathymetric gradients such as the Mid Indian Ridge Abyssal Plain (Fig. 3d).

\section{Diet}

A total of 2385 otoliths were extracted from the 132 faecal samples collected, and an increasing number of hard-prey items were observed throughout the pup-rearing period (Table 4). Approximately $18 \%$ of all otoliths, from $65 \%$ of scats, were too eroded to be identified. The proportion of eroded myctophid otoliths that could not be identified to species steadily increased throughout the study period (Table 4). Otoliths of the mesopelagic fish family Myctophidae were by far the most numerous hard-prey items identified in the scats. Highest frequency of occurrence (i.e. FO > 33\%) was found for 5 myctophid species (Table 4) that contributed to $66 \%$ of the female diet in terms of numerical abundance (NA). Myctophum phengodes and Symbolophorus spp. were the main prey consumed from summer to late autumn, but the importance of their NA declined abruptly in winter (Table 4). In contrast to Symbolophorus spp., however, $M$. phengodes had a more important decline in FO during that period. Simultaneous with this, Electrona paucirastra consumption started to increase both in terms of FO and NA during late autumn, contributing up to $43 \%$ of the winter diet (Table 4). On the other hand, Hygophum hanseni was consistently found in $44 \%$ of the scats throughout the study period, representing a mean constant abundance of $9 \%$ (Table 4). To a lesser extent, Cubiceps caeruleus and Scopelosaurus sp. represented approximately $5 \%$ each by number in the diet. C. caeruleus, however, showed an increase in both FO and NA, while Scopelosaurus sp. had a constant FO and decreasing NA throughout the study period. 
Table 4. Seasonal frequency of occurrence (FO, \%) and numerical abundance (NA, \%) of main fish species found in 132 scats of female subantarctic fur seals Arctocephalus tropicalis breeding on Amsterdam Island during the 1999 breeding season

\begin{tabular}{|c|c|c|c|c|c|c|c|c|c|c|}
\hline \multirow[t]{2}{*}{ Species } & \multicolumn{2}{|c|}{ Summer } & \multicolumn{2}{|c|}{ Early autumn } & \multicolumn{2}{|c|}{ Late autumn } & \multicolumn{2}{|c|}{ Winter } & \multicolumn{2}{|c|}{ Overall } \\
\hline & $\mathrm{FO}(\%)$ & NA $(\%)$ & $\mathrm{FO}(\%)$ & NA (\%) & FO (\%) & NA (\%) & $\mathrm{FO}(\%)$ & NA $(\%)$ & $\mathrm{FO}(\%)$ & NA $(\%)$ \\
\hline Electrona paucirastra & 3 & 0.2 & 0 & 0.0 & 51 & 22.8 & 82 & 42.9 & 35 & 18.8 \\
\hline Myctophum phengodes & 55 & 28.6 & 55 & 21.9 & 31 & 15.4 & 6 & 0.5 & 36 & 15.4 \\
\hline Symbolophorus spp. & 68 & 33.9 & 48 & 28.3 & 77 & 25.5 & 45 & 5.9 & 59 & 22.6 \\
\hline Hygophum hanseni & 39 & 7.5 & 42 & 14.8 & 51 & 8.5 & 45 & 5.9 & 44 & 9.0 \\
\hline Lampichthys procerus & 13 & 0.9 & 24 & 4.6 & 6 & 0.3 & 9 & 0.6 & 13 & 1.4 \\
\hline Unidentifiable Myctophidae & 48 & 16.7 & 64 & 14.8 & 66 & 17.3 & 85 & 24.2 & 65 & 18.5 \\
\hline Cubiceps caeruleus & 3 & 1.1 & 21 & 2.9 & 46 & 4.7 & 64 & 12.0 & 34 & 5.5 \\
\hline Scopelosaurus sp. & 35 & 7.3 & 24 & 6.3 & 23 & 1.3 & 36 & 2.7 & 29 & 3.9 \\
\hline No. of scats/identifiable otoliths & 31 & 454 & 33 & 520 & 35 & 784 & 33 & 627 & 132 & 2385 \\
\hline
\end{tabular}

Table 5. Summary of otolith length $(\mathrm{mm})$ of main fish species consumed by female subantarctic fur seals Arctocephalus tropicalis on Amsterdam Island during 1999 breeding season. na: not available

\begin{tabular}{|c|c|c|c|c|c|c|c|c|c|c|c|c|c|c|c|}
\hline \multirow[t]{2}{*}{ Major prey species } & \multicolumn{3}{|c|}{ Summer } & \multicolumn{3}{|c|}{ Early autumn } & \multicolumn{3}{|c|}{ Late autumn } & \multicolumn{3}{|c|}{ Winter } & \multicolumn{3}{|c|}{ Overall } \\
\hline & Mean & $\mathrm{SD}$ & $\mathrm{n}$ & Mean & $\mathrm{SD}$ & $\mathrm{n}$ & Mean & $\mathrm{SD}$ & $\mathrm{n}$ & Mean & $\mathrm{SD}$ & $\mathrm{n}$ & Mean & $\mathrm{SD}$ & $\mathrm{n}$ \\
\hline Electrona paucirastra & 2.45 & 0.18 & 6 & na & na & 0 & 2.95 & 0.15 & 47 & 3.05 & 0.18 & 76 & 2.99 & 0.21 & 129 \\
\hline Myctophum phengodes & 3.23 & 0.33 & 49 & 3.46 & 0.23 & 21 & 3.65 & 0.39 & 42 & na & na & 0 & 3.43 & 0.38 & 112 \\
\hline Symbolophorus spp. & 3.98 & 0.83 & 70 & 4.28 & 0.84 & 30 & 4.63 & 0.49 & 48 & 4.72 & 0.64 & 10 & 4.28 & 0.79 & 158 \\
\hline Hygophum hanseni & 1.85 & 0.30 & 20 & 1.82 & 0.43 & 24 & 2.24 & 0.29 & 34 & 2.35 & 0.32 & 17 & 2.07 & 0.40 & 95 \\
\hline
\end{tabular}

The length characteristics of the principal fish species had a similar pattern of changes throughout the study period (Table 5): Myctophum phengodes and Electrona paucirastra otolith length steadily increased from summer to winter (ANOVA, $F_{2,109}=$ $17.31, \mathrm{p}<0.001$ and $F_{2,127}=36.54$, $\mathrm{p}<0.001$, respectively), while Symbolophorus spp. and Hygophum hanseni otoliths found in summer-early autumn were significantly smaller than those found in late autumn-winter $\left(t_{156}=\right.$ $-4.752, \mathrm{p}<0.001$ and $t_{93}=-6.425$, $\mathrm{p}<0.001$, respectively).

\section{At-sea activity budget}

Maternal foraging trips were mainly composed of travelling phases $(70 \pm 10 \%$ of time at sea), whereas diving $(14 \pm 5 \%)$ and resting $(16 \pm 8 \%)$ behaviour constituted similar proportions of the females' activity budget. Although no overall seasonal trend was detected $\left(G^{2}=8.51, \mathrm{df}=6, \mathrm{p}=0.2\right)$, there was a significant difference between activity budgets occurring before and after mid-autumn (before: $12 \%$ diving, $75 \%$ travelling, $13 \%$ resting; after: $16 \%$ diving, $65 \%$ travelling, $19 \%$
Table 6. Arctocephalus tropicalis. Differences in at-sea activity budget of female subantarctic fur seals as a function of their presence in seasonal core area during the 1999 and 2002 breeding seasons. Values in bold: significant difference in Wilcoxon paired-sample test; $Z$ = Wilcoxon index; negative $Z$ values indicate greater proportion of time spent outside core area

\begin{tabular}{|c|c|c|c|c|c|c|c|c|c|c|}
\hline \multirow[t]{2}{*}{ Activity } & \multicolumn{2}{|c|}{$\begin{array}{l}\text { Summer } \\
n=9\end{array}$} & \multicolumn{2}{|c|}{$\begin{array}{c}\text { Early autumn } \\
n=9\end{array}$} & \multicolumn{2}{|c|}{$\begin{array}{l}\text { Late autumn } \\
\qquad \mathrm{n}=8\end{array}$} & \multicolumn{2}{|c|}{$\begin{array}{c}\text { Winter } \\
n=9\end{array}$} & \multicolumn{2}{|c|}{$\begin{array}{c}\text { Overall } \\
n=32\end{array}$} \\
\hline & $Z$ & $\mathrm{p}$ & $Z$ & $\mathrm{p}$ & $Z$ & $\mathrm{p}$ & $Z$ & $\mathrm{p}$ & $Z$ & $\mathrm{p}$ \\
\hline Div & 1.72 & 0.0 & 7 & $<0.01$ & 2.53 & $<0.02$ & 2.67 & $<0.01$ & 5.03 & $<0.001$ \\
\hline Travelling & -1.66 & 0.10 & -2.67 & $<0.01$ & -2.52 & $<0.02$ & -0.41 & 0.68 & -3.65 & $<0.001$ \\
\hline Resting & 0.91 & 0.36 & -0.14 & 0.89 & -1.33 & 0.18 & -2.31 & $<0.03$ & -1.54 & 0.12 \\
\hline
\end{tabular}

resting; $\left.G^{2}=11.12, \mathrm{df}=2, \mathrm{p}<0.01\right)$. The proportion of time spent travelling was significantly greater during the first 2 seasons of the pup-rearing period $\left(G^{2}=4.78\right.$, $\mathrm{df}=1, \mathrm{p}<0.02$ ). The proportion of time spent diving was always inversely related to the foraging trip duration, $\operatorname{FTD}\left(F_{1,35}=12.69, \mathrm{n}=35, \mathrm{p}<0.002, \mathrm{r}_{\mathrm{corr}}=-0.21\right)$, although the slope of the relationship varied depending on the season $\left(F_{\mathrm{FTD} \times \text { season }}=5.47, \mathrm{n}=35, \mathrm{p}<0.01\right)$. Moreover, except during the summer months, diving behaviour was predominantly observed inside the core area (Table 6), while both travelling during autumn and resting during winter were more important outside the core area (Fig. 4, Table 6). During the autumn months, the percent of time spent diving increased when inside 


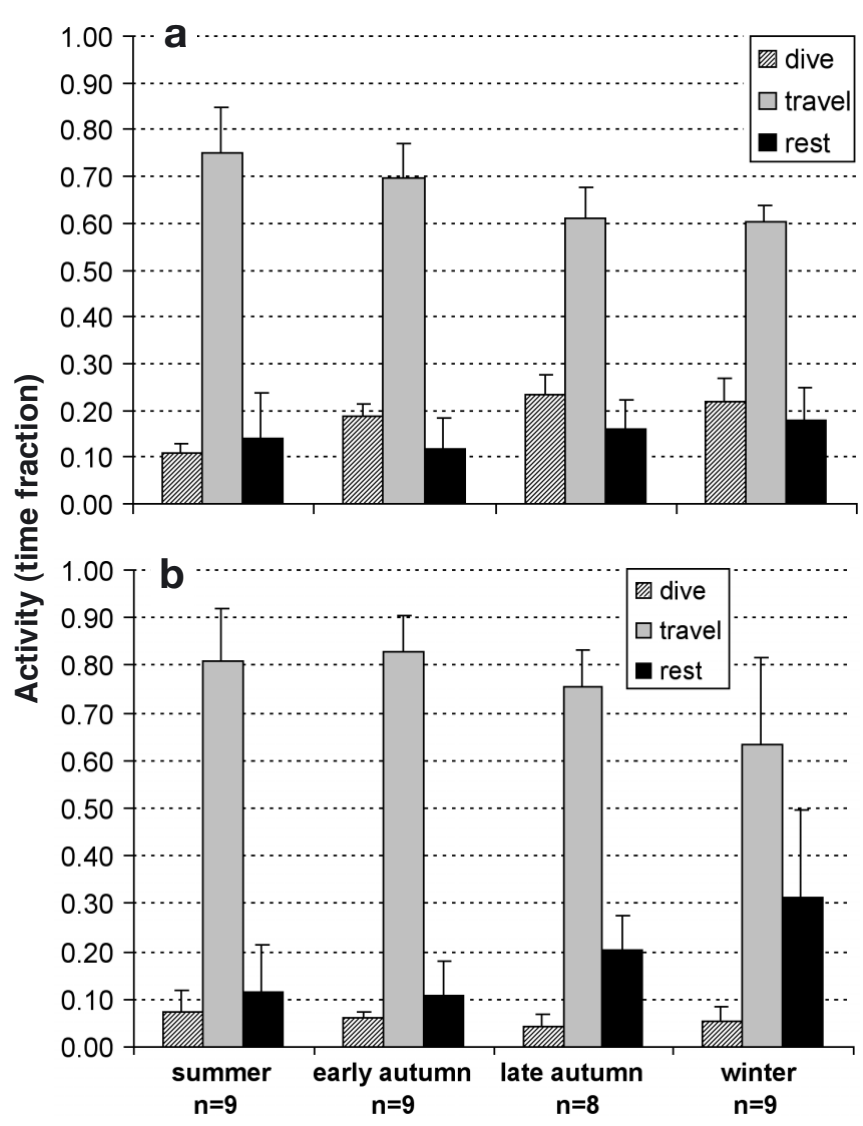

Fig. 4. Arctocephalus tropicalis. Seasonal activity budget (a) inside and (b) outside defined seasonal core area the core area to the detriment of percent time spent travelling, whereas during the winter months it was to the detriment of percent time spent resting (Fig. 4; Table 6). Moreover, while diving activity was related to (1) season, (2) presence inside the core area, and (3) the interaction between these 2 terms (Table 7), resting behaviour was only related to season, but tended to be dependent on the interaction (Table 7).

\section{Maternal performance and pup growth}

Multiple regression analyses were used to investigate the relationships between maternal performance and the resulting pup growth patterns with the following factors: (1) season, (2) foraging trip duration, (3) foraging tactics (i.e. percent time spent in the seasonal core area), (4) percent time spent diving and travelling, (5) pup characteristics (sex and body mass before suckling [pup mass, PM]), (6) maternal characteristics (i.e. age, body length) and performance. Absolute MMG reached its maximum value during the autumn months (Table 8), and was positively related to foraging trip duration $\left(F_{1,37}=7.68, \mathrm{n}=37, \mathrm{p}<0.01, \mathrm{r}_{\text {corr }}=+0.37\right)$. However, it was not related to any other factor ( $p>0.2$ in all cases), and the MMG rate decreased throughout the seasons $\left(F_{2,37}=4.83, \mathrm{n}=37, \mathrm{p}<0.02\right.$, Table 8$)$. Similarly, absolute PMG was highest during the autumn months (Table 8), and was positively related to both absolute MMG

Table 7. Arctocephalus tropicalis. Analysis (general linear model) of at-sea diving and resting behaviour of female subantarctic fur seals as a function of season, presence in main foraging ground and interaction. p: probability; n: sample size

\begin{tabular}{|c|c|c|c|c|c|c|}
\hline Dependent variable & $\mathrm{n}$ & $\mathrm{r}^{2}$ & Independent variable & df & F-ratio & $\mathrm{p}$ \\
\hline \multirow[t]{3}{*}{ Diving time/Travelling time } & 70 & 0.821 & Season & 3 & 10.91 & $<0.001$ \\
\hline & & & Core area & 1 & 207.67 & $<0.001$ \\
\hline & & & Season $\times$ core area & 3 & 16.64 & $<0.001$ \\
\hline \multirow[t]{3}{*}{ Resting time/Travelling time } & 70 & 0.305 & Season & 3 & 6.08 & 0.001 \\
\hline & & & Core are & 1 & 1.25 & 0.27 \\
\hline & & & Season $\times$ core area & 3 & 2.55 & 0.06 \\
\hline
\end{tabular}

Table 8. Arctocephalus tropicalis. Maternal foraging trip duration (FTD) and mass gain in lactating subantarctic fur seals and consequent mass gain and growth rate of their pups, throughout the breeding season. MMG: maternal mass gain; PMG: pup mass gain; GR: growth rate

\begin{tabular}{|c|c|c|c|c|c|c|c|c|c|c|c|c|}
\hline \multirow[t]{2}{*}{ Variable } & \multicolumn{3}{|c|}{ Summer } & \multicolumn{3}{|c|}{ Early autumn } & \multicolumn{3}{|c|}{ Late autumn } & \multicolumn{3}{|c|}{ Winter } \\
\hline & Mean & $\mathrm{SD}$ & $\mathrm{n}$ & Mean & $\mathrm{SD}$ & $\mathrm{n}$ & Mean & $\mathrm{SD}$ & $\mathrm{n}$ & Mean & $\mathrm{SD}$ & $\mathrm{n}$ \\
\hline FTD (d) & 15.0 & 3.4 & 9 & 26.0 & 8.2 & 9 & 22.4 & 8.4 & 14 & 29.1 & 14.6 & 8 \\
\hline $\begin{array}{l}\text { MMG }(\mathrm{kg}) \\
\text { MMG (kg d }{ }^{-1} \text { at sea) }\end{array}$ & $\begin{array}{c}6.0 \\
0.41\end{array}$ & $\begin{array}{c}1.3 \\
0.09\end{array}$ & $\begin{array}{l}9 \\
9\end{array}$ & $\begin{array}{c}8.5 \\
0.34\end{array}$ & $\begin{array}{c}2.9 \\
0.14\end{array}$ & $\begin{array}{l}9 \\
9\end{array}$ & $\begin{array}{c}7.5 \\
0.34\end{array}$ & $\begin{array}{c}3.7 \\
0.16\end{array}$ & $\begin{array}{l}14 \\
14\end{array}$ & $\begin{array}{c}5.4 \\
0.20\end{array}$ & $\begin{array}{c}4.3 \\
0.13\end{array}$ & $\begin{array}{l}8 \\
8\end{array}$ \\
\hline PMG (kg) & 2.3 & 0.9 & 9 & 3.2 & 0.8 & 9 & 3.3 & 1.2 & 14 & 2.6 & 0.9 & 8 \\
\hline PMG $\left(\mathrm{kg} \mathrm{d}^{-1}\right.$ at sea $)$ & 0.15 & 0.05 & 9 & 0.13 & 0.04 & 9 & 0.15 & 0.05 & 14 & 0.10 & 0.04 & 8 \\
\hline Pup GR $\left(\mathrm{g} \mathrm{d}^{-1}\right)$ & 21.5 & 14.5 & 9 & 24.4 & 9.0 & 9 & 14.0 & 8.0 & 14 & 1.6 & 9.7 & 8 \\
\hline
\end{tabular}


$(t=3.97, \mathrm{n}=36, \mathrm{p}<0.001)$ and foraging trip duration $(t=2.03, \mathrm{n}=36, \mathrm{p}=$ 0.05). The rate of PMG was positively correlated with the rate of MMG $(t=$ 2.52, $\mathrm{n}=37, \mathrm{p}<0.02)$, and maternal length ( $t=2.02, \mathrm{n}=37, \mathrm{p}=0.05)$ and was negatively related to foraging trip duration $(t=-3.12, \mathrm{n}=37, \mathrm{p}<0.01)$ but not with any other factors ( $p>0.2$ in all cases). Pup GR was negatively related with $\mathrm{PM}(t=-2.08, \mathrm{n}=35, \mathrm{p}<$ $0.05)$ and season $\left(F_{2,37}=3.47, \mathrm{n}=37\right.$, $\mathrm{p}<0.05)$, but no relationship was found with foraging tactics, maternal characteristics or pup sex ( $p>0.1$ in all cases).

Due to the above differences among seasons, further analyses were run for each season separately. During the summer, the MMG rate was positively related to the time spent in the core area and to the time spent diving, while pup GR was also positively related to the percent time spent in the core area (Table 9). In autumn and winter, PMG rate was negatively related to foraging trip duration, and positively related to MMG rate (Table 9). During the winter months, MMG and PMG rates were positively related to maternal length (Table 9), but not to any other maternal characteristics or foraging tactics ( $p>0.1$ in all cases). However, while pup GR was positively related to maternal length in autumn, this was not the case in winter ( $p>0.1$ in all cases). For each season, neither the sex of the pup nor maternal age represented significant factors in the models (Table 9).

\section{DISCUSSION}

Our study describes various aspects of the foraging ecology in the subantarctic fur seal females breeding on a subtropical island. This integrative approach allows us to better understand how seasonal environmental fluctuations affect breeding females' foraging features and maternal performances throughout the extended pup-rearing period.
Table 9. Arctocephalus tropicalis. Analysis (general linear model) of maternal mass gain, pup mass gain and growth rates in subantarctic fur seals in relation to variables during 1999 and 2002 breeding season on Amsterdam Island. Values in bold: significant effects after stepwise backward analysis

\begin{tabular}{|c|c|c|c|c|c|c|}
\hline $\begin{array}{l}\text { Dependent } \\
\text { variable }\end{array}$ & $\mathrm{n}$ & $r^{2}$ & Independent variable & $\mathrm{df}$ & $t$ & $\mathrm{p}$ \\
\hline \multicolumn{7}{|l|}{ Summer } \\
\hline \multirow{7}{*}{$\begin{array}{l}\text { Maternal mass } \\
\text { gain (MMG) rate }\end{array}$} & \multirow[t]{7}{*}{8} & \multirow[t]{7}{*}{0.697} & Time in core area $(\%)$ & 1 & 3.40 & $<0.02$ \\
\hline & & & Time diving $(\%)$ & 1 & 3.59 & $<0.02$ \\
\hline & & & Time travelling (\%) & 1 & -0.13 & 0.90 \\
\hline & & & Foraging trip duration (d) & 1 & -1.60 & 0.16 \\
\hline & & & Pup sex & 1 & 0.07 & 0.95 \\
\hline & & & Maternal length (cm) & 1 & -1.06 & 0.33 \\
\hline & & & Maternal age (yr) & 1 & 1.64 & 0.16 \\
\hline \multirow{9}{*}{$\begin{array}{l}\text { Pup growth } \\
\text { rate (GR) }\end{array}$} & \multirow[t]{9}{*}{8} & \multirow[t]{9}{*}{0.447} & Time in core area $(\%)$ & 1 & 3.51 & $<0.02$ \\
\hline & & & Time diving (\%) & 1 & -0.12 & 0.91 \\
\hline & & & Time travelling $(\%)$ & 1 & -1.68 & 0.14 \\
\hline & & & Foraging trip duration (d) & 1 & -2.20 & 0.07 \\
\hline & & & Pup sex & 1 & 1.70 & 0.14 \\
\hline & & & Pup mass (kg) & 1 & -0.50 & 0.64 \\
\hline & & & Maternal length (cm) & 1 & -0.63 & 0.55 \\
\hline & & & Maternal age (yr) & 1 & -0.98 & 0.37 \\
\hline & & & MMG rate (kg time at $\mathrm{sea}^{-1}$ ) & 1 & 0.62 & 0.56 \\
\hline \multicolumn{7}{|l|}{ Autumn } \\
\hline \multirow{9}{*}{$\begin{array}{l}\text { Pup mass } \\
\text { gain (PMG) rate }\end{array}$} & \multirow[t]{9}{*}{20} & \multirow{9}{*}{0.525} & Time in core area $(\%)$ & 1 & 0.09 & 0.93 \\
\hline & & & Time diving $(\%)$ & 1 & -0.42 & 0.68 \\
\hline & & & Time travelling $(\%)$ & 1 & -0.91 & 0.38 \\
\hline & & & Foraging trip duration (d) & 1 & -2.78 & $<0.02$ \\
\hline & & & Pup sex & 1 & 1.33 & 0.20 \\
\hline & & & Pup mass (kg) & 1 & 0.85 & 0.41 \\
\hline & & & Maternal length (cm) & 1 & 1.38 & 0.18 \\
\hline & & & Maternal age (yr) & 1 & 0.39 & 0.70 \\
\hline & & & MMG rate (kg time at $\left.\mathrm{sea}^{-1}\right)$ & 1 & 3.37 & $<0.01$ \\
\hline \multirow{9}{*}{$\begin{array}{l}\text { Pup growth } \\
\text { rate (GR) }\end{array}$} & \multirow[t]{9}{*}{15} & \multirow[t]{9}{*}{0.372} & Time in core area (\%) & 1 & 1.37 & 0.19 \\
\hline & & & Time diving $(\%)$ & 1 & -1.66 & 0.12 \\
\hline & & & Time travelling $(\%)$ & 1 & 0.74 & 0.47 \\
\hline & & & Foraging trip duration (d) & 1 & 0.17 & 0.86 \\
\hline & & & Pup sex & 1 & 0.72 & 0.47 \\
\hline & & & Pup mass (kg) & 1 & -1.60 & 0.13 \\
\hline & & & Maternal length (cm) & 1 & 2.50 & $<0.01$ \\
\hline & & & Maternal age (yr) & 1 & 0.90 & 0.38 \\
\hline & & & MMG rate $\left(\mathrm{kg}\right.$ time at $\left.\mathrm{sea}^{-1}\right)$ & 1 & 0.95 & 0.35 \\
\hline \multicolumn{7}{|l|}{ Winter } \\
\hline \multirow{7}{*}{$\begin{array}{l}\text { Maternal mass } \\
\text { gain (MMG) rate }\end{array}$} & \multirow[t]{7}{*}{8} & \multirow[t]{7}{*}{0.818} & Time in core area (\%) & 1 & -0.68 & 0.53 \\
\hline & & & Time diving (\%) & 1 & 0.38 & 0.71 \\
\hline & & & Time travelling $(\%)$ & 1 & -0.76 & 0.48 \\
\hline & & & Foraging trip duration (d) & 1 & -0.84 & 0.43 \\
\hline & & & Pup sex & 1 & 0.88 & 0.44 \\
\hline & & & Maternal length (cm) & 1 & 5.20 & $<0.01$ \\
\hline & & & Maternal age (yr) & 1 & -0.41 & 0.70 \\
\hline \multirow{9}{*}{$\begin{array}{l}\text { Pup mass } \\
\text { gain (PMG) rate }\end{array}$} & 8 & 0.471 & Time in core area (\%) & 1 & 1.11 & 0.32 \\
\hline & & & Time diving (\%) & 1 & 1.80 & 0.12 \\
\hline & & & Time travelling $(\%)$ & 1 & -0.29 & 0.78 \\
\hline & & & Foraging trip duration (d) & 1 & -2.82 & $<0.04$ \\
\hline & & & Pup sex & 1 & 0.44 & 0.69 \\
\hline & & & Pup mass (kg) & 1 & 2.03 & 0.09 \\
\hline & & & Maternal length (cm) & 1 & 2.22 & 0.07 \\
\hline & & & Maternal age (yr) & 1 & -1.40 & 0.23 \\
\hline & & & MMG rate ( $\mathrm{kg}$ time at $\left.\mathrm{sea}^{-1}\right)$ & 1 & 1.76 & 0.13 \\
\hline
\end{tabular}




\section{Foraging trip duration and spatial distribution}

In summer and early autumn, the STF's northern limit was situated roughly $200 \mathrm{~km}$ south of Amsterdam Island. This frontal structure extended from 37 to $45^{\circ} \mathrm{S}$, representing a water mass approximately $800 \mathrm{~km}$ wide (Fig. 3a,b). During late autumn, this water mass drifted northward by $2-3^{\circ}$ latitude (Fig. 3c), with its winter southern limit reaching up to $42^{\circ} \mathrm{S}$ (Fig. 3d). The continuity observed in SST changes between early autumn 2002 and late autumn 1999 supports the observation that oceanographic features in the study area display similar changes in both years (Belkin \& Gordon 1996). During the winter months, the STF's extension increased tremendously (up to a width of $1400 \mathrm{~km}$, and its northern limit was situated as far as $28^{\circ} \mathrm{S}$ (Fig. 3d). The surface increase of this frontal structure reflected a lower SST gradient within the whole study area, especially in the southern part of the STF, the surface of which doubled throughout this period (Fig. 3d).

Although inter-individual differences occurred in all seasons, foraging trip duration and concurrent distance from the breeding colony increased throughout the pup-rearing period. Furthermore, this is the first time that such long distances between the rookery and foraging areas have been reported for a pup-rearing female of any fur seal species. However, the time spent at sea was not influenced by the device attached to the seal, as non-equipped females showed identical foraging trip durations.

Kernel analyses were mainly performed on geolocation fixes and used to define seasonal core areas of individual trip core-fixes, thus making the definition of seasonal core areas rather imperfect at a small scale. However on a large scale, analyses showed that lactating females' feeding trips were not randomly dispersed around Amsterdam Island. The seals mainly exploited the STF waters, but exhibited considerable variation in their at-sea distribution throughout the pup-rearing period in response to temporal shifts in this frontal structure and pup provisioning constraints (i.e. fasting abilities). During the summer and early autumn, foraging activity was spread over the entire range of the STF's SST; this is similar to the behavioural pattern described by Georges et al. (2000). Some females, however, used colder waters than reported by Georges et al. (2000), with seals travelling within the northern part of the subantarctic front (SAF). During late autumn, all seals travelled towards an area situated SE of the rookery and in line with the $3000-3500 \mathrm{~m}$ isometric contours (Fig. 3c). During the winter period, the seasonal northward shift in the STF and the concurrent decreasing SST gradient is hypothesised to be associated with lower resource availability (Mann \& Lazier 1991). This hypothesis is in accordance with previous studies showing that foraging trip duration increases as food availability declines (Croxall et al. 1988, Lunn et al. 1993). Consequently, female foraging trips were longer, but also much more dispersed than in previous phases (Fig. 3). Interestingly, the variability in both foraging trip duration and maximum distance from the rookery was very high during the winter months (Fig. 2). This raises the hypothesis that females may use 2 different foraging options during that period, with either short trips $(2-3 \mathrm{wk})$ relatively close to the colony, or very long trips (5-7 wk) into the West Australian Ridge area (Table 3, Fig. 3d). It is not clear, however, what constituted the determinants of that choice, and more winter foraging trip records are needed to clarify this question. Nevertheless, all foraging habitats seemed to be located in areas of higher bathymetric gradient such as the West Australian Ridge, excluding flat bottom areas such as the Mid Indian Ridge Abyssal Plain.

\section{Diet}

As we have just outlined a concomitant change in environmental features and seals' foraging location patterns, one might expect a corresponding fluctuation in diet throughout the same period. In this study, 7 identified prey species occurred in more than $10 \%$ of the scats, with 5 of these representing $66 \%$ of the female diet. This finding suggests that subantarctic fur seals consume a wider range of prey species than other otariids (Green et al. 1991, Ochoa-Acuna \& Francis 1995, Robinson et al. 2002). However, our study covered the whole pup-rearing period, and seasonal NA showed that only 2 to 3 species constituted the main components of the seals' seasonal diet. This low prey diversity may reflect the availability of a limited number of prey species in the study area in a given season.

The fish diet of female subantarctic fur seals breeding at Amsterdam Island differed completely in terms of prey species from that found in previous studies of conspecifics breeding on different islands (Goldsworthy et al. 1997, Klages \& Bester 1998, Robinson et al. 2002) and in studies of other subtropical species (OchoaAcuna \& Francis 1995). This confirms that differences in diet between and within seal species are more influenced by the biogeography of fish species than by phylogenetic patterns (Robinson et al. 2002). Of the 3 main Myctophydae species consumed during the summer and early autumn (Myctophum phengodes and Symbolophorus barnardi), 2 are subtropical species exhibiting surface-migrating nycthemeral patterns (Hulley 1981). Moreover, the third species ( $S$. boops) is known to occur in colder waters south of the subtropical convergence and north of the SAF (Hulley 
1981). These results support the finding that the STF is exploited by the majority of seals, although some individuals extended their trip to within the northern part of the SAF.

In late autumn and winter, Electrona paucirastra progressively replaced Symbolophorus spp. and Myctophum phengodes (Table 4 ) as the main prey species of the seals. This myctophid, representing $43 \%$ of the winter diet, is known to be a surface migrating species occurring within the STF (Hulley 1981). Variations in SST are usually related to the position of frontal zones and corresponding water-mass dynamics (Belkin \& Gordon 1996). Such fluctuations directly affect the distribution and abundance of zooplankton (Pakhomov et al. 1994), fishes, squids, and ultimately top marine predators (Deacon 1982). Our study also indicated that variations in the location of the foraging areas and the change in seals' diet patterns throughout the breeding season are consistent with fluctuations in the STF location. Otariids have opportunistic feeding habits (Antonelis et al. 1984, Kajimura 1984), and their seasonal variations in diet are likely to be a reflection of changes in prey availability, with the seals taking advantage of the most available prey inhabiting the different water masses they successively exploit throughout the pup-rearing period.

However, our results presumably led to some underestimate in FO and NA of the 5 main myctophiid species (Myctophum phengodes, Symbolophorus spp., Hygophum hanseni and Electrona paucirastra) consumed by fur seal females in Amsterdam Island, especially for those prey consumed further away from the colony (Dellinger \& Trillmich 1988). This hypothesis is supported by the steady increase of unidentified myctophiid species in the diet throughout the season: the concurrent increase of foraging trip duration implies extended digestion processes, which may affect the degree of otolith abrasion (Green et al. 1991). However, contrary to previous studies (Goldsworthy et al. 1997, Robinson et al. 2002), we observed an increase in average otolith length of the main prey species consumed throughout the pup-rearing period (Table 5). These changes in otolith length, and thus the fishes' respective body sizes, may be due to growth of the fishes during this period. However, this increasing size of prey items could also be due to seasonal changes in the water masses, with the concomitant fish patches being exploited by the seals during different seasons.

\section{At-sea activity budget}

In each phase, females making shorter foraging trips spent more time diving than those undertaking longer trips; this is consistent with the behaviour of
Antarctic fur seals reported by Boyd et al. (1991). Considering the negative relationship between the atsea metabolic rate and the proportion of time spent diving found by Arnould et al. (1996), we hypothesise that the rate of energy expenditure per unit time may be lower, and thus more advantageous, in short-trip females within a given period. However, the extrapolation of this hypothesis may not be valid under different environmental conditions (see Arnould et al. 1996). Because of probable variations in food availability in the early and late pup-rearing periods (see Croxall et al. 1988, Lunn et al. 1993, this study), the simultaneous increase in both diving and resting rates throughout lactation does not allow us to propose a similar hypothesis for females foraging during the earlier versus the latter part of the lactation period.

During summer, a similar at-sea activity budget was observed inside and outside the defined core area (Fig. 4). This suggests that the summer foraging ground is located in an immediately accessible area of homogeneous prey availability, so that seals coming from the rookery also feed on their way to the core area (Fig. 3a). In contrast, during the latter part of the lactation period, the increase in diving effort occurs especially inside the seasonal core area (Fig. 4), which is likely to reflect a female behavioural adjustment to declining food availability outside the seasonal core area (Croxall et al. 1988, Lunn et al. 1993, Georges et al. 2000). This tends to confirm that females encountered more variable prey availability during the latter part of the pup-rearing period, and consequently foraged in more clearly delimited core areas. These zones, however, were not directly accessible from the rookery (Fig. 3b-d), and females had to travel large distances across areas of low prey availability in order to reach them. During winter inside the core area, the percent time spent diving increased to the detriment of resting, whereas this was to the detriment of travelling during the previous phases (Fig. 4). We suggest that the females could not reduce their travel time within the winter core area because this zone contained fewer, more scattered, and more localised prey patches than in the previous phases. All these results are consistent with the increasing weakness and northward shift of the SST gradient observed in the study area throughout the breeding season (see Fig. 3).

\section{Maternal performance and pup growth}

When all phases were pooled, absolute MMG and PMG were positively related to the female's previous foraging trip duration. A longer foraging trip thus permitted the female to gain more mass at a lower diving rate, as previously described in Arnould et al. (1996). 
Furthermore, PMG rate was positively related to maternal length and MMG rate, but negatively related to FTD, and therefore tended to decrease throughout the breeding season. This is consistent with previous results of Georges \& Guinet (2000a), and confirms that FTD and maternal body characteristics are the main factors influencing PMG patterns. Pup GR was negatively related to PM and breeding season. This was in accordance with the concurrent increasing FTD and distances covered, which reflected a strong decline in food availability throughout the pup-rearing period (Croxall et al. 1988, Lunn et al. 1993).

During the summer, no significant influence of maternal characteristics was detected, but both MMG rate and pup GR were positively related to the proportion of time spent inside the core area. The MMG rate was also found to be positively related to the percentage of time spent diving. This influence of foraging tactics may be explained by the relatively short trips exhibited by the females during the summer: a higher diving rate within an homogeneous environment may become crucial for greater foraging success when encountering conditions of good prey accessibility, while in winter the location of good prey patches may be a more important component of foraging success than the diving effort itself. The negative trend detected with increasing foraging trip duration also supports the hypothesis that maternal foraging patterns during summer may be mainly driven by pup fasting and ingestion abilities rather than by female characteristics (Georges \& Guinet 2000a). Our sample size may, however, have been too small to detect any effect of the other factors tested during that phase.

In autumn, pup GR was strongly related to maternal length, and PMG rate was positively correlated with MMG rate. Similarly, during the winter months, MMG and PMG rates were positively related to maternal body length. Therefore, pup growth may depend more on maternal size when foraging trips are longer: longer females are probably faster swimmers and are able to store a larger absolute amount of body reserves. In our study we were unable to detect any influence of maternal age, and older mothers did not appear to take advantage of their experience in the raising of their pup. However, our sample size was probably too small to detect such an effect. Moreover, this study dealt with a single foraging trip per individual, and experience may be more decisive when considering pup global GR during the entire pup-rearing period. We therefore were not able to assess the influence of longterm factors, such as foraging trip regularity, a factor that was found to be determinant in a previous study (Georges \& Guinet 2000a).

During the autumn months, PMG rate and subsequent GR were similar to those found in the summer, but abruptly declined in winter. The autumn peak in milk gross energy (Georges et al. 2001) may compensate for longer trips undertaken by the females during that period. However, although pups are adapted to long-term fasting periods (Beauplet et al. 2003), the concurrent decreasing energy content of the milk (Georges et al. 2001) and increasing requirements of pregnancy (Oftedal 1985) are likely to reduce a female's capacity to fulfill the requirements of its pup during winter. Furthermore, the greater mean seasonal trip duration (see Fig. 2) compared to that previously reported in the same colony (Georges \& Guinet 2000a, Georges et al. 2000) is in accordance with the finding of a long-term trend in decreasing pup growth performances throughout the decade (see Chambellant et al. 2003), suggesting that the subantarctic fur seal population on Amsterdam Island may be reaching its carrying capacity (Chambellant et al. 2003).

Overall, in this study we observed the longest foraging trips ever reported for any pup-rearing female otariid (Gentry \& Kooyman 1986, Goldsworthy 1992, Figueroa 1994, Francis et al. 1998), which were consistent with the extensive distances covered. This suggests that these seals encounter extremely low food availability throughout the breeding period (Croxall et al. 1988, Lunn et al. 1993), and particularly during its latter part. In this context, body length represents an important component of the body's reserve strategy, especially since foraging zones are located far away from the rookery. Female subantarctic fur seals breeding on Amsterdam Island have the largest body size of this species (Bester \& Van Jaarsveld 1994, Robinson et al. 2002, Dabin et al. in press), and the milk they produce is among the richest of all otariids (Georges et al. 2001). This suggests a phocid-like strategy (Trillmich 1996); that is, they may rely more on their fat reserves than any other otariid species.

Acknowledgements. We are grateful to the members of the 50th and 53rd research missions at Amsterdam Island for their assistance in the field, in particular F. Le Bouard, D. Thuillier, J. Hubert, O. Lardeux, and M. Leblanc. We especially wish to thank the 50th VAT team, F. Dewilde, G. Schlosser, M. Lecointre, T. Levenes, and G. Receveur for their invaluable help. We also thank J. Arnould, O. Lourdais, F. Bonadonna, S. Luque, and E. De Santo for their useful comments on earlier drafts of the manuscript, as well as D. Pinaud for helpful advice with GIS. The activity budget data-processing was made at the Service Informatique du COM, on an openMosix cluster system, with the great help of M. Libes. This research program was conducted under the ethics and scientific approval of the IPEV Ethics Committee (Programme 109). The field work was supported financially and logistically by Terres Australes et Antarctiques Françaises (TAAF) and Institut Polaire Paul-Emile Victor (IPEV). 


\section{LITERATURE CITED}

Antonelis GA, Fiscus CH, DeLong RL (1984) Spring and summer prey of California sea lions, Zalophus californianus, at San Miguel Island, California 1978-79. Fish Bull 82:67-76

Arnould JPY, Hindell MA (2002) Milk consumption, body composition and pre-weaning rates of Australian fur seal (Arctocephalus pusillus doriferus) pups. J Zool 256:351-359

Arnould JPY, Boyd IL, Speakman JR (1996) The relationship between foraging behaviour and energy expenditure in Antarctic fur seals. J Zool 239:769-782

Beauplet G, Guinet C, Arnould JPY (2003) Body composition changes, metabolic fuel use and energy expenditure during extended fasting in subantarctic fur seal (Arctocephalus tropicalis) pups at Amsterdam Island. Physiol Biochem Zool 76:262-270

Belkin IM, Gordon AL (1996) Southern Ocean fronts from the Greenwich meridian to Tasmania. J Geophys Res 101: 3675-3696

Bester MN, Van Jaarsveld AS (1994) Sex-specific and latitudinal variance in postnatal growth of the subantarctic fur seal (Arctocephalus tropicalis). Can J Zool 72:1126-1133

Bonadonna F, Lea MA, Guinet C (2000) Foraging routes of Antarctic fur seals (Arctocephalus gazella) investigated by the concurrent use of satellite tracking and time-depth recorders. Polar Biol 23:149-159

Boyd IL (1996) Temporal scales of foraging in a marine predator. Ecology 77:426-434

Boyd IL (1999) Foraging and provisioning in Antarctic fur seals: interannual variability in time-energy budgets. Behav Ecol 10:198-208

Boyd IL, Lunn NJ, Barton T (1991) Time budgets and foraging characteristics of lactating Antarctic fur seals. J Anim Ecol 60:577-592

Boyd IL, Arnould JPY, Barton T, Croxall JP (1994) Foraging behaviour of Antarctic fur seals during periods of contrasting prey abundance. J Anim Ecol 63:703-713

Boyd IL, McCafferty DJ, Reid K, Taylor R, Walker TR (1998) Dispersal of male and female Antarctic fur seals (Arctocephalus gazella). Can J Fish Aquat Sci 55:845-852

Chambellant M, Beauplet G, Guinet C, Georges JY (2003) Long-term evaluation of pup growth and pre-weaning survival rates in subantarctic fur seals, Arctocephalus tropicalis, on Amsterdam Island. Can J Zool 81:1229-1239

Croxall JP (1992) Southern Ocean environmental changes: effects on seabird, seal, and whale populations. Phil Trans R Soc Lond B 338:319-328

Croxall JP, McCann TS, Prince PA, Rothery P (1988) Reproductive performance of seabirds and seals at South Georgia and Signy Island, South Orkney Islands, 1976-1987: implications for Southern Ocean monitoring studies. In: Sahrhage D (ed) Antarctic Ocean and resources variability. Springer-Verlag, Berlin, p 261-285

Dabin W, Beauplet G, Guinet C (2002) Response of wild subantarctic fur seal (Arctocephalus tropicalis) females to ketamine and tiletamine-zolazepam anesthesia. J Wildl Dis 38:846-850

Dabin W, Beauplet G, Crespo EA, Guinet C (in press) Age structure, growth and demographic parameters in breeding-age subantarctic fur seal (Arctocephalus tropicalis) females. Can J Zool

Deacon GER (1982) Physical and biological zonation in the Southern Ocean. Deep-Sea Res 29:1-15

Dellinger T, Trillmich F (1988) Estimating diet composition from scat analysis in otariid seals (Otariidae): is it reliable? Can J Zool 66:1865-1870

Figueroa AL (1994) Early lactation and attendance behaviour of the Guadalupe fur seal females Arctocephalus townsendi. MS thesis, University of California, Santa Cruz

Francis J, Boness D, Ochoa-Acuna H (1998) A protracted foraging and attendance cycle in female Juan Fernandez fur seals. Mar Mamm Sci 14:552-574

Gentry RL, Kooyman GL (1986) Fur seals: maternal strategies on land and at sea. Princeton University Press, Princeton, NJ

Georges JY, Guinet C (2000a) Maternal care in the subantarctic fur seals on Amsterdam Island. Ecology 81: 295-308

Georges JY, Guinet C (2000b) Early mortality and perinatal growth in the subantarctic fur seals (Arctocephalus tropicalis) on Amsterdam Island. J Zool 251:277-287

Georges JY, Bonadonna F, Guinet C (2000) Foraging habitat and diving activity of lactating subantarctic fur seals in relation to sea surface temperatures on Amsterdam Island. Mar Ecol Prog Ser 196:291-304

Georges JY, Groscolas R, Guinet C, Robin JP (2001) Milking strategy in subantarctic fur seals (Arctocephalus tropicalis) breeding at Amsterdam Island: evidence from changes in milk composition. Physiol Biochem Zool 74: $548-559$

Goldsworthy SD (1992) Maternal care in three species of southern fur seals (Arctocephalus spp.). PhD thesis, Monash University, Melbourne

Goldsworthy SD (1995) Differential expenditure of maternal resources in Antarctic fur seals, Arctocephalus gazella, at Heard Island, southern Indian Ocean. Behav Ecol 6:218-228

Goldsworthy SD, Hindell MA, Crowley HM (1997) Diet and diving behaviour of sympatrically breeding fur seals Arctocephalus gazella and Arctocephalus tropicalis at Macquarie Island. In: Hindell MA, Kemper C (eds) Marine mammal research in the Southern Hemisphere, Vol 1: status, ecology, and medicine. Surrey Beatty \& Sons, Chipping Norton, p 151-163

Green K, Williams R, Burton HR (1991) The diet of Antarctic fur seals during the late autumn and early winter around Heard Island. Antarct Sci 3:359-361

Guinet C, Georges JY (2000) Growth in pups of the subantarctic fur seal (Arctocephalus tropicalis) on Amsterdam Island. J Zool 250:289-296

Guinet C, Jouventin P, Georges JY (1994) Long term population changes of fur seals Arctocephalus gazella and Arctocephalus tropicalis on subantarctic (Crozet) and subtropical (St Paul and Amsterdam) islands and their possible relationship to El Niño Southern Oscillation. Antarct Sci 6:473-478

Guinet C, Koudil M, Bost CA, Durbec JP, Georges JY, Mouchot MC, Jouventin P (1997) Foraging behaviour of satellite-tracked king penguins in relation to sea-surface temperatures obtained by satellite telemetry at Crozet Archipelago, a study during three austral summers. Mar Ecol Prog Ser 150:11-20

Guinet C, Dubroca L, Lea MA, Goldsworthy SD, Cherel Y, Duhamel G, Bonadonna F, Donnay JP (2001) Spatial distribution of foraging in female Antarctic fur seals Arctocephalus gazella in relation to oceanographic variables: a scale-dependent approach using geographic information systems. Mar Ecol Prog Ser 219:251-264

Hill RD (1994) Theory of geolocation by light levels. In: Le Bœuf BJ, Laws RM (eds) Elephant seals: population ecology, behavior, and physiology. University of California Press, Berkeley, p 227-236

Hooge PN, Eichenlaub B (1997) Animal movement extension to ArcView. Alaska Biological Science Center, US Geological Survey, Anchorage (see also www.absc.usgs.gov/ glba/gistools) 
Houston AI, Thompson WA, Gaston AJ (1996) The use of a time and energy budget model of a parent bird to investigate limits to fledging mass in the thick-billed murre. Funct Ecol 3:255-265

Hulley PA (1981) Results of the research cruises of FRV 'Walther Herwig' to South America. LVIII. Family Myctophidae. Arch FischWiss 31(Beih I):1-300

Ihaka R, Gentleman R (1996) R: language for data analysis and graphics. J Comput Graph Stat 5:299-314

Kajimura H (1984) Opportunistic feeding of the northern fur seal, Callorhinus ursinus, in the eastern north Pacific Ocean and eastern Bering Sea. NOAA Tech Rep NMFS SSRF-779:1-49

Klages NTW, Bester MN (1998) Fish prey of fur seals Arctocephalus spp. at subantarctic Marion Island. Mar Biol 131:559-566

LeBœuf BJ, Crocker DE, Costa DP, Blackwell SB, Webb PM, Houser DS (2000) Foraging ecology of northern elephant seals. Ecol Monogr 70:353-382

Lunn NJ, Boyd IL, Croxall JP (1993) Factors affecting the growth rate and mass at weaning of Antarctic fur seals at Bird Island, South Georgia. J Mammal 74:908-919

Lutjeharms JRE, Valentine HR (1984) Southern Ocean thermal fronts south of Africa. J Deep-Sea Res 31:1461-1475

Mann KH, Lazier JRN (1991) Dynamics of marine ecosystems, biological-physical interactions in the ocean. Blackwell Scientific Publications, London

McConnell BJ, Chambers C, Fedak MA (1992) Foraging ecology of southern elephant seals in relation to the bathymetry and productivity of the Southern Ocean. Antarct Sci 4:393-398

Ochoa-Acuna H, Francis JM (1995) Spring and summer prey of the Juan Fernandez fur seals, Arctocephalus philippii. Can J Zool 73:1444-1452

Oftedal OT (1985) Pregnancy and lactation. In: Hudson RJ, White RG (eds) Bioenergetics of wild herbivores. CRC Press, Boca Raton, p 215-239

Orians GH, Pearson NE (1979) On the theory of central place foraging. In: Horn DJ, Stairs ET, Mitchell RD (eds) Analysis of ecological system. Ohio State University Press, Columbus, p 155-177

Pakhomov EA, McQuaid CD (1996) Distribution of surface zooplankton and seabirds across the Southern Ocean. Polar Biol 16:271-286

Pakhomov EA, Perissinotto R, McQuaid CD (1994) The comparative structure of the macrozooplankton/micronekton communities of the subtropical and antarctic polar fronts. Mar Ecol Prog Ser 111:155-169

Editorial responsibility: Otto Kinne (Editor),

Oldendorf/Luhe, Germany
Pinaud D, Weimerskirch H (2002) Ultimate and proximate factors affecting the breeding performance of a marine top-predator. Oikos 99:141-150

Powell RP (2000) Animal home ranges and territories and home range estimators. In: Boitani L, Fuller TK (eds) Research techniques in animal ecology: controversies and consequences. Columbia University Press, New York, p 65-110

Reynolds RW, Smith TM (1994) Improved global sea surface temperature analyses. J Climate 7:929-948

Robinson SA, Goldsworthy SG, Van den Hoff J, Hindell MA (2002) The foraging ecology of two sympatric fur seal species Arctocephalus gazella and Arctocephalus tropicalis at Macquarie Island during the austral summer. Mar Freshw Res 53:1071-1082

Roux JP (1987) Recolonization processes in the subantarctic fur seal, Arctocephalus tropicalis, on Amsterdam Island. NOAA Tech Rep NMFS 51:189-194

Silverman ED (1986) Density estimation for statistics and data analysis. Chapman \& Hall, London

Smale MJ, Watson G, Hecht T (1995) Otolith atlas of Southern African marine fishes. JBL Smith Institute of Ichthyology, Grahamstown

Sokal RR, Rolf FJ (1981) Biometry, 2nd edn. WH Freeman, New York

Stephens DW, Krebs JR (1986) Foraging theory. Princeton University Press, Princeton, NJ

Taillade M (1993) Trends in satellite-based animal tracking. In: Mancini P, Fioretti S, Cristalli C, Bedini R (eds) Biotelemetry XII. Litografia Felici, Pisa, p 291-297

Tollu B (1974) L'otarie de l'île d'Amsterdam Arctocephalus tropicalis (Gray 1872). PhD thesis, Université de Paris 7

Trillmich F (1996) Parental investment in pinnipeds. Adv Stud Behav 25:533-577

Wartzok D (1991) Physiology of behaviour in pinnipeds. In: Renouf D (ed) Behaviour of pinnipeds. Chapman \& Hall, London, p 237-299

Weimerskirch H, Salamolard M, Sarrazin F, Jouventin P (1993) Foraging strategy of wandering albatrosses through the breeding season: a study using satellite. Auk 110:325-342

Wood AG, Naef-Daenzer B, Prince PA, Croxall JP (2000) Quantifying habitat use in satellite-tracked pelagic seabirds: application of kernel estimation to albatross locations. J Avian Biol 31:278-286

Ydenberg RC, Welham CVJ, Schmid-Hempel R, SchmidHempel P, Beauchamp G (1994) Time and energy constraints and the relationships between currencies in foraging theory. Behav Ecol 5:28-34

Submitted: October 21, 2003; Accepted: February 3, 2004

Proofs received from author(s): May 19, 2004 